

\title{
Article 51's reporting requirement as a space for legal argument and factfulness*
}

\author{
Larissa van den Herik ${ }^{* *}$
}

\begin{abstract}
Uncertainties continue to exist as regards the function, contents and application of the proportionality principle in the context of the right to self-defence. Similarly, it has been suggested that the principle of necessity gains new meaning in the context of non-state actor self-defence as it provides the basis for an unwilling/unable test, but this test remains disputed. While appreciating the wealth of scholarly writings on these ad bellum principles, this chapter aims to reflect on how States can be pulled into the conversation more clearly with a view to clarifying the law. It explores how more space can be created for legal argument and factfulness in use of force discourse by States. Specifically, the chapter seeks to enhance necessity and proportionality discourse through the strengthening of Security Council reporting structures. Building on ideas to "proceduralise Article 51", the chapter suggests the development of reporting requirements for any use of force on the basis of a duty to explain. It also proposes a more comprehensive architectural rethinking of the institutional environment in which adherence to and application of the necessity and proportionality principles are tested and contested.
\end{abstract}

\section{Introduction}

It is generally accepted that the principles of necessity and proportionality apply to the exercise of self-defence. Nonetheless, disagreement remains regarding their function, contents and application in concrete cases. ${ }^{1}$ These disagreements and continuous uncertainties are discussed in detail in other chapters. In light of this opacity, it may be useful to complement the substantive debate with some thoughts of a more institutional and procedural nature. This

\footnotetext{
* The title word "factfulness” refers to the book by Hans Rosling, which highlights contrasts between worldly understandings informed by instincts, preconceptions and bias versus those based on data acquired through statistics, graphs and questionnaires, H. Rosling and others, Factfulness: Ten Reasons We're Wrong About the World--and Why Things Are Better Than You Think, Flatiron Books, 2018.

${ }^{* *}$ Larissa van den Herik is Vice Dean of Leiden Law School and Professor of Public International Law at the Grotius Centre for International Legal Studies at Leiden University. I am grateful to the editors and all participants to the Westpoint seminar for their immense valuable comments and suggestions on an earlier draft of this chapter. I am also grateful for research assistance offered by Charlotte Vercraeye, Teaching and Research Assistant, LLM advanced student at Leiden University 2017-2018.

${ }^{1}$ See generally, J. Gardam, Necessity, Proportionality the Use of and Force by States, Cambridge Univeersity Press, 2004, D. Kretzmer, The inherent right to self-defence and proportionality in jus ad bellum, 24 European Journal of International Law 1, 2013, pp. 235-282, C. Tams and J. Devaney, Applying necessity and proportionality to anti-terrorist self-defence, 45 Israel Law Review, 1, pp. 91-106, E. Cannizzaro, Contextualizing proportionality: jus ad bellum and jus in bello in the Lebanese war, 88 International Review of the Red Cross 864 , December 2006, pp. 779-792.
} 
chapter explores possibilities of enhancing necessity and proportionality discourse through the widening and deepening of Security Council reporting requirements. The aim is to rethink and to design structures that pull States more clearly into the conversation. Building on ideas to "proceduralise Article 51",2 the chapter suggests the development of reporting requirements for any use of force. It also invites a more comprehensive architectural rethinking of the institutional environment in which adherence to and application of the proportionality and necessity principles are tested and contested. The central idea behind this is that the necessity and proportionality principles require strong institutions to gain meaning.

The chapter is inspired by Thomas Franck's scholarship on proportionality discourse. ${ }^{3}$ Franck makes the argument that the proportionality principle can become more determinate through the "second opinion of legitimate institutions", 4 whereby he points mainly to jurisprudential streams generated by different international courts. This chapter explores possibilities beyond courts. It looks at options for further proceduralization and institutionalization within political fora, in particular the Security Council setting. Building also on notions of legal diplomacy, a duty to explain and a "culture of justification", the chapter interrogates through which structures necessity and proportionality discourse can be rendered more articulate and factful in concrete situations in which force is used. The two leading questions that this chapter addresses are: (i) which procedural or institutional structures at Security Council level would strengthen necessity and proportionality discourse in concrete cases of use of force thereby also rendering the discourse more fact- and evidence-based? And (ii) what can be learned of the UN sanctions machinery in this regard?

The chapter starts the analysis with a focus on self-defence and the unclarity surrounding the proportionality and necessity principles (section 1) and it introduces Article 51's reporting requirement (section 2). It then discusses the potential for deepening the discourse (section 3) and it presents ideas to widen the discourse to other unilateral uses of force, specifically intervention by invitation (section 4). Finally, a comparative analysis of UN sanctions architecture is made to offer a first reflection regarding platform for the discourse (section 5), followed by some brief concluding thoughts.

\section{Self-defence and necessity and proportionality discourse}

Article 51 is the only Charter provision that offers a legal basis for the unilateral use of force. As such, it has been invoked to justify different scenarios of self-defence and thus uses of force of different dynamic, intensity and nature. The existing uncertainty as to how the necessity and proportionality principles condition the use of force in self-defence, is exacerbated by this further differentiation of uses of force covered under the same general label of self-defence. In addition to inter-State self-defence, uses of force to protect own nationals, against (terrorist) threats by non-state actors, against anticipated attacks and against cyberattacks have all been justified by reference to Article 51. What exactly application of the necessity and proportionality principles entails in these different scenarios may vary. This thus adds a layer

\footnotetext{
${ }^{2}$ Larissa van den Herik, Proceduralizing Article 51, Zeitschrift für ausländisches öffentliches Recht und Völkerrecht 77: 65-67 (2017).

${ }^{3}$ T. Franck, On proportionality and countermeasures in international law, 102 American Journal of International Law 4, 2008, pp. 715-767.

${ }^{4}$ Ibid., p. 717.
} 
of complexity to the existing discussions on temporal, geographical and other dimensions of necessity and proportionality ${ }^{5}$ and specifically on what constitutes the appropriate test for jus ad bellum proportionality determination; a discussion that navigates between a tit-for-tat test, a means-end test and a narrow proportionality test. ${ }^{6}$ Different scenarios of self-defence may call for different types of proportionality tests. Moreover, specific scenarios of self-defence may give rise to new factors that should inform a proportionality calculus within a concrete test. For instance, in cases of self-defence against non-state actors, the contribution or attitude of the host State affects proportionality assessments including discussions on what constitutes a legitimate aim. ${ }^{7}$ It may also be that there are multiple legal bases underlying a certain use of force all involving their own proportionality calculi and necessity tests, as was the case in the IS strikes which were justified by a combination of individual and collective self-defence and / or additionally consent. ${ }^{8}$

In addition to the variety of tests that may generally inform necessity and proportionality assessments in the different scenarios of self-defence as well as the variety of factors that may inform these tests in those distinct scenarios, the factual situations to which the principles are applied also offer endless variability. It has often been observed that ultimately concrete application of the necessity and proportionality principles hinges on the specific circumstances and contingencies of a situation. ${ }^{9}$ Application of these principles thus also vastly depends on how the relevant facts of a situation are determined and measured. ${ }^{10}$ This raises questions of evidentiary standards ${ }^{11}$ and even if standards are agreed upon, different perspectives may still

\footnotetext{
${ }^{5}$ See in this regard also the discussion in Eliav Lieblich's chapter on the continuous versus the static approach to the proportionality principle. Similar to Lieblich, Gardam also makes the argument that jus ad bellum proportionality remains relevant through the course of the hostilities and must be constantly assessed, whereas Dinstein disputes this. J. Gardam, Proportionality and Force in International Law, 87 American Journal of International Law, 3 (1993), pp. 391-413 and Y. Dinstein, War, Aggression and Self-Defence, Cambridge University Press, $5^{\text {th }}$ edition, 2011, p. 262.

${ }^{6}$ D. Kretzmer, The inherent right to self-defence and proportionality in jus ad bellum, 24 European Journal of International Law 1, 2013, pp. 235-282. Kretzmer's revisiting of the proportionality principle was critiqued by G. Nolte, Multipurpose self-defence, proportionality disoriented: A response to David Kretzmer, 24 European Journal of International Law 1, 2013, pp. 283-290.

${ }^{7}$ D. Akande and T. Liefländer, Clarifying necessity, imminence, and proportionality in the law of self-defence, 107 American Journal of International Law (2013), pp. 562-570.

${ }^{8}$ B. Egan, International Law, Legal Diplomacy, and the Counter-ISIL Campaign: Some Observations, 92 International Law Studies, (2016), pp. 235-248.

${ }^{9}$ C. Tams and J. Devaney, Applying necessity and proportionality to anti-terrorist self-defence, 45 Israel Law Review, 1, pp. 91-106, p. 102.

${ }^{10}$ Zimmerman submits that application of the jus in bello proportionality principle requires an "intense verification of the relevant facts on the ground". As for jus ad bellum proportionality, he states that, "It would accordingly be sufficient, in order for the reply to the armed attack to be considered legal under international law, that a bona fide claim could be made, that it could have ex ante been expected that the measures of self-defense, given the available information, would be proportionate in light of the anticipated armed attack.” A. Zimmerman, The Second Lebanon War: Jus ad bellum, jus in bello and the Issue of Proportionality, in A. von Bogdandy and R. Wolfrum, (eds.), 11 Max Planck Yearbook of United Nations Law, 2007, p. 99-141, on p. 137 and p. 125 resepectively.

${ }^{11}$ M.E. O’Connell, Evidence of terror, 7 Journal of Conflict and Security Law 1, 2002, pp. 19-36. See for treatment of evidence in self-defence context by the ICJ, Case concerning aermed activities on the territory of Congo, Demotratic Republic of Congo v. Uganda, Judgement of 19 December 2005, paras. 120-134. See for particular evidentiary problems and their limits in contexts of risk-assessments to determine whether and attack is imminent and there is thus a basis for anticipatory self-defence, N. Lubell, The problem of imminence in an uncertain world, in M. Welller (ed.), The Oxford Handbook of the Use of Force in International Law, Oxford University Press, 2015, pp. 697-719, pp. 713-716.
} 
give rise to different appreciation of the facts. As observed by Kretzmer, there is a self-evident bias of a State under attack, which extends to States that sympathize with the victim State, whereas the attitude by uninvolved States and outsiders may give rise to other perspectives, also informed by considerations of an entirely different nature. ${ }^{12}$ Hence, in the words of Schmitt, "all such assessments [including necessity and proportionality assessments] are inherently subjective and contextual." 13

These statements tie in with a louder chorus that depicts proportionality as extremely flexible and context-specific, dependent on circumstances at hand, and lacking certainty, ${ }^{14}$ or even as a mere rhetorical tool. ${ }^{15}$ In a 2008 AJIL article on Proportionality of Countermeasures in International Law, the late Thomas Franck countered the idea that proportionality was like beauty, existing only in the eye of the beholder. Accepting the indeterminacy of proportionality, Franck argued that the dynamic quality of vague principles like proportionality lies in their operational effect of creating a space for second opinions. ${ }^{16}$ Rather than seeing proportionality as a principle offering direct substantive guidance, Franck emphasized the institutional dimension of the proportionality principle and particularly the role of international courts in generating jurisprudence that clarifies the principle's contours through a precedential approach. In his article, Franck demonstrated how international courts had cast light on the concept of proportionality in different judicial settings also regarding trade disputes and human rights litigation. In the jus ad bellum context, the ICJ's case law was spotlighted as offering guidance on proportionality. ${ }^{17}$

The ICJ is not always considered a beacon of clarity though, and various authors have in fact critiqued the ICJ for not offering sufficient guidance on what jus ad bellum proportionality means, ${ }^{18}$ or for insisting on a retrospective approach that is out of tune with the generally accepted qualitative-prospective approach. ${ }^{19}$ More generally the problem may be that jus ad bellum litigation at the ICJ remains sparse. ${ }^{20}$ Therefore, the central premise of this chapter is to

\footnotetext{
${ }^{12}$ D. Kretzmer, The

inherent right to self-defence and proportionality in jus ad bellum, European Journal of International Law, volume 24, no. 1, pp. 235-282, p. 238.

${ }^{13}$ Michael Schmitt, Counter-Terrorism and the Use of Force in International Law, Marshll Centre Paper, No. 5, pp. 1-107, p. 70.

${ }^{14}$ See S. Etezazian, The nature of the self-defence proportionality requirement, 3 Journal on the Use of Force and International Law, 2, 2016, 260-289 and further references given therein.

$15 \mathrm{~J}$. Gardam, Necessity, Proportionality, the Use of and Force by States, Cambridge University Press, 2004, p. 187.

${ }^{16}$ Thomas Franck, On Proportionality of Countermeasures in International Law, The American Journal of International Law, Vol. 102, No. 4 (Oct., 2008), pp. 715-767, p. 717.

${ }^{17}$ Ibid., pp. 719-722.

${ }^{18}$ See e.g., D. Akande and T. Liefländer, Clarifying necessity, imminence, and proportionality in the law of selfdefence, 107 American Journal of International Law (2013), pp. 562-570, p. 567. For an overall appraisal of the ICJ's jus ad bellum jurisprudence, see C. Gray, The International Court of Justice and the Use of Force, in C. Tams and J. Sloan, The Development of International Law by the International Court of Justice, Oxford University Press, 2013, pp. 237-261.

${ }^{19}$ C. Tams, The necessity and proportionality of anti-terrorist self-defence, L. van den Herik and N. Schrijver (eds.), Counter-Terrorism Strategies in a Fragmented International Legal Order, Cambridge University Press, 2013, pp. 373-421, pp. 387-388.

${ }^{20}$ For a general inquiry on rationale for States to present jus ad bellum cases to the ICJ, see C. Gray, Why state resort to litigation in cases concerning the use of force, in N. Klein (ed.), Litigating international law disputes -
} 
take Franck's idea one step further and to look beyond international courts to find other platforms that could offer a space for proportionality discourse. Parliamentary inquiries and debates can serve a useful role in this regard. Yet, given its primacy in matters of international peace and security, the Security Council is of course the inevitable and prime location to explore in this context. Article 51's reporting requirement may offer an entry for such explorations.

\section{The reporting requirement of Article 51}

As per Article 51, States retain the inherent but temporary right to defend themselves, "until the Security Council has taken measures necessary to maintain international peace and security". The second sentence of Article 51 reads,

"Measures taken by Members in the exercise of this right of self-defence shall be immediately reported to the Security Council and shall not in any way affect the authority and responsibility of the Security Council under the present Charter to take at any time such action as it deems necessary in order to maintain or restore international peace and security.”

Article 51 thus prescribes that States acting in self-defence shall report their actions immediately to the Security Council and that the Security Council may then take over, thereby subscribing to the Charter's $\tau \dot{\varepsilon} \lambda$ o $\varsigma$ of centralization of military action, which - as is well-known - has not materialized in practice. ${ }^{21}$

The word "shall" has been understood as being directive but not mandatory in the sense that failure to report does not invalidate the claim of self-defence as such, ${ }^{22}$ nor does mere fulfillment of the reporting requirement render the underlying self-defence action legal per se. In this sense, the reporting requirement rather has a procedural or technical function, and is not substantive in nature. It thus follows, also flowing from the ICJ's dicta in the Nicaragua case, that the reporting requirement pertains to Article 51 only and does not exist in parallel under customary international law, ${ }^{23}$ but the relevance of this finding is rather limited given the UN Charter's universal ratification.

wieghing the balance, Cambridge University Press, 2014, pp. 305-329. For an analysis of the ICJ's case law on the use of force, also see C. Kress, The International Court of Justice and the 'Principle of Non-Use of Force', in M. Weller (ed.), Oxford handbook on the use of force in international law, OUP, 2015, pp. 561-604.

${ }^{21}$ M. Hakimi, The jus ad bellum's regulatory form, 112 American Journal of International Law 2, 2018, pp. 151190, p. 158 ("the more Article 51 permits defensive force [...], the more its shifts decisionmaking from the Council to state acting unilaterally”).

${ }^{22}$ D.W. Greig, Self-defence and the Security Council: What does Article 51 require? 40 International and Comparative Law Quarterly, 1991, pp. 384. For an analysis on the status of the reporting obligation, see Yoram Dinstein, War, Aggression and Self-Defence, CUP, $5^{\text {th }}$ ed., 2011, pp. 239-241, with reference also to the ICJ's statement in the Nicaragua Judgement that, "the absence of a report may be one of the factors indicating whether the State in question was itself convinced that it was acting in self-defence.” ICJ, Case Concerning Military and Paramilitary Activities in and against Nicaragua, Nicaragua versus United States of America, Judgement of 27 June 1986, para. 200. Also see, James A. Green, “The Article 51 Reporting Requirement for Self-Defense Actions”, in 55 Virginia Journal of International Law 3, 2015, pp. 563-624. And T. Ruys, 'Armed Attack and Article 51 of the UN Charter: Evolutions in customary law and practice, Cambridge University Press, 2010, pp. 68-74.

23 "Whatever influence the Charter may have had on customary international law in these matters, it is clear that in customary international law it is not a condition of the lawfulness of the use of force in self-defence that a 
The word "reported" is not further elaborated on. Early incarnations of Article 51 required that the Security Council "be kept fully informed". ${ }^{24}$ The subsequent use of the word "report" seems to pose a lower bar as to the level of legal and factual detail that should be provided. The wording of the other authentic languages varies: Arabic (تبلغ= reported), Chinese (应立向安全 理事会报告 = shall be immediately reported) French (portées à la connaissance = brought to the attention), Russian (“сообщены = communicated; сообщить means to inform, to send a message) and Spanish (“communicadas” = communicated). The French, Russian and Spanish texts may imply a mere notification requirement without any need for further substantiation. Indeed, one of the main purposes of the reporting requirement is to publicise a claim of selfdefence and thus to put it on the agenda of the Security Council and the international community more broadly. Nonetheless, serious engagement at a central level does require a certain substantiation to allow for a meaningful discussion. Scholarly arguments have been advanced that reports must include evidence regarding the alleged circumstances that triggered the attack and some information on defensive measures taken. ${ }^{25}$ This raises questions of the extent to which such disclosure obligations can apply, also taking into account the highly sensitive nature of underlying intelligence information. ${ }^{26}$ These questions tie in with other rationales of the reporting requirement regarding transparency and justification. ${ }^{27}$ These broader rationales may also inform timing and frequency of reporting and in this respect the argument has been made that States "must report afresh when the material facts have changed, for example, where selfdefence is used as a basis for the use of force on the territory of a new State, or new parties are added to the conflict."28

In a comprehensive piece on Article 51's reporting requirement, Green analysed the practice of reporting. His findings were that, in the period 1998-2013, a majority of self-defence actions was reported to the Security Council. ${ }^{29}$ On substantive quality of the reports, Green noted that

\footnotetext{
procedure so closely dependent on the content of a treaty commitment and of the institutions established by it, should have been followed.” ICJ, Case Concerning Military and Paramilitary Activities in and against Nicaragua, Nicaragua versus United States of America, Judgement of 27 June 1986, para. 200.

${ }^{24}$ James A. Green, “The Article 51 Reporting Requirement for Self-Defense Actions”, in 55 Virginia Journal of International Law 3, 2015, p. 603.

${ }^{25}$ Yutaka Arai-Takahashi, Yutaka Arai-Takahashi, Shifting Boundaries of the Right of Self-Defence - Appraising the Impact of the September 11 Attacks on Jus Ad Bellum , 36 International Lawyer, 2002, pp. 1081-1102.

${ }^{26}$ Yutaka Arai-Takahashi, Yutaka Arai-Takahashi, Shifting Boundaries of the Right of Self-Defence - Appraising the Impact of the September 11 Attacks on Jus Ad Bellum, 36 International Lawyer, 2002, pp. 1081-1102, p. 1095; M. Wood, International law and the use of force: what happens in practice? 53 Indian Journal of International Law, 2013, pp. 345-367, p. 350; Michael Schmitt, Counter-Terrorism and the Use of Force in International Law, Marshll Centre Paper, No. 5, pp. 1-107, pp. 69-72.

27 Report of the Special Rapporteur on extrajudicial, summary or arbitrary executions, Christof Heyns, 13 September 2013, UN Doc. A/68/382, para. 93.

${ }^{28}$ Ibid., para. 94.

${ }^{29}$ James A. Green, “The Article 51 Reporting Requirement for Self-Defense Actions”, in 55 Virginia Journal of International Law 3, 2015, p. 585. The reporting is still not 100\% complied with, see e.g. A. Deeks, A Call for Article 51 Letters, Lawfare, 25 June 2014, noting the absence of Article 51 letters following the Kenyan strikes in Somalia against al Shabaab, the Israeli airstrikes in Syria in response to a cross-border attack killing an Israeli teenager, and the Syrian air strikes in western Iraq against ISIS.
} 
reports were "extremely cursory, for the most part including little factual or legal detail". ${ }^{30} \mathrm{By}$ way of example, Green pointed out that only three of the 200 reports submitted between 19982013 referred to the proportionality principle, and only one of those made an actual attempt to substantiate the claim that the proportionality principle had been adhered to. ${ }^{31}$ These figures may not have taken account of letters which did not refer to the proportionality principle expressly, but which did make indirect reference to the spirit of the principle for instance by highlighting the aim of operations. Specifically in the context of the operations against $\mathrm{Al}$ Qaeda, the majority of Article 51 letters did pay tribute to the proportionality principle emphasising that the self-defense measures were targeting Al-Qaeda as a terrorist organization and the Taliban regime as their host, but not the Afghan population..$^{32}$ In contrast, France was more evasive, stating only,

On instructions from my Government, following the terrorist attacks perpetrated in the United States of America on 11 September 2001, I have the honour to inform you that, in accordance with the exercise of the inherent right of individual or collective self-defence (Article 51 of the Charter), referred to in Security Council resolution 1368 (2001), and in response to the encouragement addressed to Member States by the Council in paragraph 5 of its resolution 1378 (2001), France has undertaken action involving the participation of military air, land and naval forces. ${ }^{33}$

Such a letter does not offer much beyond mere notification.

Practice since 2013 has been rather different. In the context of operations against IS specifically, a variety of States have more expressly reported on necessity and proportionality. In their Article 51 letters, States almost invariably posited that they took "necessary and proportionate measures” in individual and/or collective self-defence. ${ }^{34}$ Going beyond Operation Enduring

\footnotetext{
${ }^{30}$ James A. Green, “The Article 51 Reporting Requirement for Self-Defense Actions”, in 55 Virginia Journal of International Law 3, 2015, p. 604.

${ }^{31}$ James A. Green, “The Article 51 Reporting Requirement for Self-Defense Actions”, in 55 Virginia Journal of International Law 3, 2015, p. 605.

${ }^{32}$ UN Doc. S/2001/946, 7 October 2001, para. 4 (US lettter); UN Doc. S/2001/947, 7 October 2001, paras. 3-4 (UK letter); UN Doc. S/2001/1005, 24 October 2001, para. 2 (Canada lettter); UN Doc. S/2001/1104, 23 November 2001, para. 6 (Australia letter); UN Doc. S/2001/1127, 29 November 2001, para. 2 (Germany letter); UN Doc. S/2001/1171, 6 December 2001, para. 3 (Netherlands letter); UN Doc. S/2001/1193, 18 December 2001, para. 3 (New Zealand lettter); UN Doc. S/2001/275, 15 March 2002, para. 1 (Poland letter).

${ }^{33}$ UN Doc. S/2001/1103, 23 November 2001.

34 The US indicated that it had "initiated necessary and proportionate military actions in Syria”, UN Doc. S/2014/695, 23 September 2014; The UK reported, "The United Kingdom fully supports these international efforts, whose purpose is to end the continuing attack on Iraq, to protect Iraqi citizens and to enable Iraqi forces to regain control of the borders of Iraq by striking ISIL sites and military strongholds in Syria, as necessary and proportionate measures, UN Doc. S/2014/851, 25 November 2014, and on a later occasion, "the United Kingdom of Great Britain and Northern Ireland carried out a precision air strike against an ISIL vehicle in which a target known to be actively engaged in planning and directing imminent armed attacks against the United Kingdom was travelling. This air strike was a necessary and proportionate exercise of the individual right of self-defence of the United Kingdom. UN Doc. S/2015/688, 7 September 2015, para. 2, and again later "the United Kingdom of Great Britain and Northern Ireland is taking necessary and proportionate measures against ISIL/Daesh in Syria, as called for by the Council in resolution 2249 (2015), in exercise of the inherent right of individual and collective selfdefence, UN Doc. S/2015/928, 3 December 2015, para. 2. Also see the letter of Canada, UN Doc. S/2015/221, 31 March 2015, para. 1; letter of Australia, UN Doc. S/2015/693, 9 September 2015, paras. 5 and 6; Letter of Germany, UN Doc. S/2015/946, 10 December 2015, paras. 1 and 3; letter of Denmark, UN Doc. S/2016/XX, 11 January 2016, para. 1; letter of Netherlands, UN Doc. S/2016/132, 10 February 2016, paras. 1 and 2; Letter of
} 
Freedom which was targeting the terrorist organization as well as the supportive Taliban regime, the Article 51 letters regarding IS-operations consistently underscore that they target IS specifically thereby subscribing to an interpretation of proportionality that excludes attacks against the host State. ${ }^{35}$ In addition, the letters generally adhere to a prospective understanding of the proportionality principle, presenting their actions as a response to a threat while also referring to constant and continuing armed attacks on Iraq from safe havens in Syria. In their letters, States articulated concrete purposes of their actions, such as "to end the continuing attacks on Iraq, to protect Iraqi citizens, and ultimately to enable and arm Iraqi forces to perform their task of regaining control of the Iraqi borders", ${ }^{36}$ and aiming at "further degrading ISIL's ability to carry out attacks" 37 , and to "to prevent and suppress terrorist acts committed by ISIL and to eradicate the safe haven that ISIL has established over significant parts of Iraq and Syria." 38 This may offer insight into which aims are considered and presented as legitimate. Yet, as is well-known, significant debate remains as to whether the Article 51 letters can be interpreted as offering support for the unwilling and unable-test, and some States' deliberate ambiguity is not particularly helpful in this regard. ${ }^{39}$ The claim has also been made that certain States attempt to rewrite the UN Charter through their Article 51 letters. ${ }^{40}$

It is also the case that letters and their contents often remain uncontested - apart from the victim State response. ${ }^{41}$ In this regard, Turkey's reporting on Operation Olive Branch can be mentioned. It reads as follows,

In countering the threat of terrorism, our response has always been proportionate, measured and in line with the right of self-defence, as defined in Article 51 of the Charter of the United Nations. Accordingly, Turkey successfully concluded Operation Euphrates Shield last year, through which 2,015 km2 of land was cleared of Deash and a safe haven free of terror could be established, which enabled some of the displaced Syrians to return safely and voluntarily to their homes. However, the threat of terrorism from Syria targeting our borders has not ended. The recent increase in rocket attacks and harassment fire directed at Hatay and Kilis provinces of Turkey from the Afrin region of Syria, which is under the control of the PKK/KCK/PYD/YPG

\footnotetext{
Norway, UN Doc. S/2016/513, 3 June 2016, paras. 1 and 3; Letter of Belgium, UN Doc. S/2016/523, 7 June 2016, paras. 1 and 3.

${ }^{35}$ E.g., the letters of Canada and Australia specify, "These military actions are not aimed at Syria or the Syrian people, nor do they entail support for the Syrian regime.” UN Doc. S/2015/221, 31 March 2015, para. 4 and UN Doc. S/2015/693, 9 September 2015, para. 5. Similarly, Germany, Norway and Belgium stated, "These measures are directed against ISIL, not against the Syrian Arab Republic.” UN Doc. S/2015/946, 10 December 2015, para. 1, UN Doc. S/2016/513, 3 June 2016, para. 3; UN Doc. S/2016/523, 7 June 2016, para. 3.

${ }^{36}$ Letters of US and UK, UN Doc. S/2014/695, 23 September 2014 and UN Doc. S/2014/851, 25 November 2014.

${ }^{37}$ Letter of Canada, UN Doc. S/2015/221, 31 March 2015, para. 4.

${ }^{38}$ Letter of The Netherlands, UN Doc. S/2016/132, 10 February 2016, paras. 1 and 2.

${ }^{39}$ Arguing that there is no broad support for the unwilling and unable standard, see e.g., J. Brunnée and Stephen J. Toope, Self-Defence against Non-State Actors: Are Powerful States Willing but Unable to Change International Law, 67 ICLQ April 2018, pp. 263-286. For a different assessment, see E. Chachko and A. Deeks, "Who is on Board with "Unwilling and Unable”, Lawfare, 10 October 2016. On strategic ambiguity, also see M. Milanovic, Belgium’s Article 51 Letter to the Security Council [UPDATED], EJIL: Talk!, 17 June 2016.

40 17th Summit of Heads of State and Government of the Non-Aligned Movement, Island of Margarita, Bolivarian Republic of Venezuela, 17 - 18 September 2016, NAM 2016/CoB/DOC.1. Corr.1, para. 25.2.

${ }^{41}$ In response to the letters and operations, Syria has pointed out that the self-defence actions did not meet various criteria, including the requirement that the response be temporary, UN Doc. S/2015/1048, 29 December 2015. It also argued that the operations caused destruction of Syrian infrastructure, economic facilities and social institutions, UN Doc. S/2016/820, 29 September 2016.
} 
terrorist organization, has resulted in the deaths of many civilians and soldiers and has left many more wounded. The risk of Deash elements infiltrating Turkey via this area and targeting the security of Turkey as well as the European countries is also heightened owing to the recent movements of Deash terrorists coming into the Afrin region from other parts of Syria. In order to counter this terrorist threat, Turkey initiated a military operation on 20 January 2018 against these terrorist elements. The operation is aimed at ensuring our border security, neutralizing terrorists in Afrin and saving the brotherly Syrians. Accordingly, the operation will target only terrorists and their hideouts, shelters, emplacements, weapons, vehicles and equipment. All precautions have been taken to avoid collateral damage. ${ }^{42}$

This letter, and particularly the underlying operation, has been critiqued for not meeting Article 51's requirements, in particular the requirement that there be an (imminent) armed attack, for not adhering to the principles of necessity and proportionality and for failing to sufficiently substantiate its claims. ${ }^{43}$ Such critique has not been echoed at Security Council level though.

The Article 51 letters, when taken together, offer insight into views and practices regarding the application of the necessity and proportionality principles, specifically in a non-State actor context. This underscores that reporting may generate further clarity on the contents of the necessity and proportionality principles in different scenarios. However, as can be expected, scholars disagree on the meaning of the reports, and third States generally withhold from disclosing a view on other States' letters unless they are the victim State or otherwise involved. Scholarly disagreement results, in part, from the fact that the reports are still fairly general without concrete assessments and factual detail. ${ }^{44}$ Moreover, reporting which does not match the facts on the ground is not necessarily exposed as such at Security Council level.

\section{Deepening Article 51's reporting requirement: towards a duty to explain and substantiate claims of proportional self-defence?}

Hence, despite a possible peak in necessity and proportionality reporting, the current practice still leaves room for arguments favouring a more meaningful approach to Article 51's reporting requirement. Such arguments find a basis in relevant policy and scholarly documents on selfdefence, such as the Leiden Policy Recommendations ${ }^{45}$ and the Chatham House Principles of International Law on the Use of Force by States in Self-Defence. ${ }^{46}$

The Leiden Policy Recommendations underscore the obligation of States to justify and explain their actions. The Recommendations specifically concern self-defence against non-state actors but the core idea has broader application. As the excerpts below demonstrate, the

\footnotetext{
${ }^{42}$ UN Doc. S/2018/53, 21 January 2018, paras. 4-8.

${ }^{43}$ A. Peters, The Turkish Operation in Afrin (Syria) and the Silence of the Lambsm EJIL: Talk!, 30 January 2018. ${ }^{44}$ See for a similar observation made in a different context, C. Tams, The necessity and proportionality of antiterrorist self-defence, L. van den Herik and N. Schrijver (eds.), Counter-Terrorism Strategies in a Fragmented International Legal Order, Cambridge University Press, 2013, pp. 373-421, pp. 418-421.

45 The Leiden Policy Recommendations were the outcome of a consultative expert process, organized with the full support of the Netherlands Ministry of Foreign Affairs. They offer expert perspectives aimed at clarifying the law and they highlight areas in which greater consensus needs to be pursued in particular also regarding self-defence against non-state actors. They are published in 57 Netherlands International Law Review 3: 531-551 (2010).

${ }^{46}$ Chatham House Principles of International Law on the Use of Force by States in Self-Defence, October 2005, as also published in 55 International and Comparative Law Quarterly 4: 963-972 (2008).
} 
Recommendations insist on several occasions on the burden of States using force in selfdefence to make their case. They state:

"Self-defence may also be necessary if the armed attack cannot be repelled or averted by the territorial State. States relying on self-defence must therefore show that the territorial State's action is not effective in countering the terrorist threat.”

"Any use of force in anticipatory self-defence should be justified publicly by reference to the evidence available to the State concerned; the facts do not speak for themselves, and the State should explain, as fully as it is able to do, the nature of the threat and the necessity for anticipatory military action." ${ }^{47}$

Specifically on proportionality, the Leiden Policy Recommendations add,

"In order to be proportionate, measures of self-defence must be limited to what is required to repel or avert the armed attack. Proportionality in this sense requires states regularly to monitor on-going measures of self-defence and ensure that they remain defensive in character. This may entail limitations on the intensity and duration of force employed and on the theatre and target of operations. In particular, it will normally mean that measures of self-defence against suspected terrorists must be directed primarily against the terrorist groups responsible for the armed attack in question or their facilities. Only in exceptional circumstances will self-defence justify the use of force against the armed forces or facilities of the territorial state, for example, in circumstances where the territorial state is supporting suspected terrorists, as in Afghanistan in 2001."

"Unnecessary or disproportionate use of force cannot be justified as a measure of self-defence under international law. As the application of both factors is heavily fact-dependent, states using force in self-defence should be prepared to make publicly available information and data that will support the necessity and proportionality of their conduct. International law does not prevent third states from scrutinising the necessity and proportionality of self-defence operations or from requesting further evidence." ${ }^{8}$

These excerpts underscore the requirement to factually substantiate a claim of self-defence.

The Chatham House Principles of International Law on the Use of Force by States in SelfDefence also accentuate the eminence of facts and public justification. Principle 4 on anticipatory self-defence states that, "force may be used only on a proper factual basis and after a good faith assessment of the facts." This is further elaborated as follows,

"Each case will necessarily turn on its own facts."

“The determination of 'imminence' is in the first place for the relevant state to make, but it must be made in good faith and on grounds which are capable of objective assessment. Insofar as this can reasonably be achieved, the evidence should be publicly demonstrable. Some kinds of evidence cannot be reasonably produced, whether because of the nature or source, or because it

\footnotetext{
${ }^{47}$ Leiden Policy Recommendations on Counterterrorism and International Law, 2010, paras. 42, 48 respectively (emphasis by author).

${ }^{48}$ Leiden Policy Recommendations on Counterterrorism and International Law, 2010, paras. 43, 44.
} 
is the product of interpretation of many small pieces of information. But evidence is fundamental to accountability, and accountability to the rule of law. The more far-reaching, and the more irreversible its external actions, the more a state should accept (internally as well as externally) the burden of showing that its actions were justifiable on the facts. And there should be proper internal procedures for the assessment of intelligence and appropriate procedural safeguards." 49

The principles on self-defence against an imminent or actual armed attack by non-State actors as proposed by Bethlehem and published in the American Journal of International Law require a strong, reasonable and objective basis for relevant conclusions, but they do not articulate a concomitant obligation to explain how exactly such conclusions are drawn and corroborated. ${ }^{50}$

Nonetheless, given the centrality of the prohibition of the use of force and its cornerstone-nature in the present-day international legal order, it is not entirely illogical to require substantiated justification of unilateral nonconformity. Indeed, it flows from the exceptional nature of selfdefence as well as the spirit of the UN Charter and the framing of relevant provisions, that States invoking Article 51 of the UN Charter should not only notify the Security Council, but that the word "report" is more demanding and that States should additionally and in light of all relevant circumstances provide appropriate justification. ${ }^{51}$ Following this reasoning, States relying on self-defence should construct their justifications in a legally plausible sense that adheres to the strictures and phraseology of Article 51 and in addition, the duty to justify and explain can be said to encapsulate the requirement to factually substantiate a claim of proportional selfdefence. In case of more exceptional uses of self-defence, such as self-defence against non-state actors, anticipatory self-defence and anticipatory self-defence against non-state actors, an even greater imperative to explain exists, as in these cases the exceptionality of self-defence is pushed even further. The exact contents of the duty to report may vary in the different scenarios though. Anticipatory self-defence hinges on the notion of "imminence" and thus involves a threat assessment which leaves even greater scope for subjectivity in the analysis. ${ }^{52}$ Inevitably, this affects the factual contents of reporting, but it does not remove the rationale of explaining and justifying per se.

The idea of necessity and proportionality discourse and use of force reporting ties in with notions of legal diplomacy, a duty to explain and "a culture of justification”, presented by Brian Egan, Chimène Keitner and Harold Koh. With specific reference to the counter-ISIL campaign, Brian Egan underscored that public explanations of legal positions are an important element of legal diplomacy. ${ }^{53}$ Egan indicated that a public conversation on legal positions may be informed

\footnotetext{
${ }^{49}$ Chatham House Principles of International Law on the Use of Force by States in Self-Defence, October 2005, Principle 4 and commentary.

${ }^{50}$ D. Bethlehem, Principles relevant to the scope of a State's right of self-defence against an imminent or actual armed attack by non-State actors, 106 American Journal of International Law 769-777, 2012, para. 7, 12. The Principles were critiqued for this lacuna, by E. Wilmshurst and M. Wood, Self-defence by non-State actors: reflections on the "Bethlehem Principles", 107 American Journal of International Law, 2013, pp. 386-395, p. 394 ("The principles would have done well to insert cautionary words, as in the Chatham House principles, about the need for a good faith assessment of the facts”).

${ }^{51}$ Leiden Policy Recommendations on Counterterrorism and International Law, 2010, para. 36.

${ }^{52}$ N. Lubell, The problem of imminence in an uncertain world, in M. Weller (ed.), The Oxford Handbook of the Use of Force in International Law, Oxford University Press, 2015, pp. 697-719, p. 718.

53 B. Egan, International Law, Legal Diplomacy, and the Counter-ISIL Campaign: Some Observations, 92 International Law Studies, (2016), pp. 235-248, p. 244.
} 
by concurrent private consultations, and he sees such intertwined public and private engagements as an indispensable ingredient of international partnerships and coalitions. ${ }^{54}$ Publicizing legal positions may also be the start of a broader conversation with other States. Adversary or other disagreeing States may react on legal and factual positions taken and this conversation can subsequently create a feedback loop that ultimately contributes to clarifying and crystallizing the contents of the law and legal principles at stake. Portrayed this way, nonreporting effectively amounts to an omission or at least a diminished ability to shape public discourse. ${ }^{55}$ Hence, bypassing the question regarding the legal nature of the obligation, the more compelling argument may be that reporting is generally in States' self-interest. Reporting allows States to shape the normative environment in which they operate in addition to cultivating partnerships. ${ }^{56}$ More concretely, reporting on the necessity and proportionality requirements with legal substantiation and factual articulation specifies and consolidates what necessity and proportionality require, thereby also operationalizing these principles in nontraditional invocations of self-defence. Additionally, reporting as an accountability process also has the effect of improving the ex ante integrity of decision-making and thereby contributes to norm-internalization. ${ }^{57}$

Despite such advantages, States have been diagnosed as being generally hesitant to state their legal and factual position in detail. They prefer to keep maximum flexibility and to preserve the possibility to change position at a later stage. States tend to present skeleton arguments, possibly also to ensure that they do not prejudice potential ICJ proceedings or other accountability processes. The criminalization of the use of force may inadvertently have enhanced this reflex and it may further disincentivize States to present their case. ${ }^{58}$ Such transparency cost of operationalizing the crime of aggression within the ICC is not a given though. States retain an overarching interest not to lose sway over use of force discourse and thus to participate in it. As underlined by Schmitt in relation to IHL, State silence may cede the initiative and power over law development to others. ${ }^{59}$ Moreover, denial and secrecy over the facts of concrete cases can also be costly in a different respect, as widespread and inaccurate claims may fill the void left by a silent State. ${ }^{60}$ Secrecy will in any event be increasingly difficult to sustain given open source investigations through new cybertechnologies by private agencies such as Bellingcat

\footnotetext{
54 Ibid.

${ }^{55}$ See for a similar argument in relation to covert action, A. H. Perina, Black holes and open secrets: the impact of covert action on international law, 53 Columbia Journal of Transnational Law, 2015, pp. 507-583, p. 511 ("But the void created by a silent state compels courts to turn to other sources.”).

${ }^{56}$ C. Keitner, Explaining international acts, McGill Law Journal (forthcoming).

${ }^{57}$ C. Keitner, Explaining international acts, McGill Law Journal (forthcoming). H. Koh, The legal adviser's duty to explain, 41 Yale Journal of International Law 2016, pp. 189-211.

${ }^{58}$ The criminalization of the use of force was enacted through amendments to the ICC Statute adopted at the ICC Review Conference Kampala on 11 June 2010, Resolution RC/Res.6, and the subsequent activation of the ICC's jurisdiction on 14 December 2017, Resolution ICC-ASP/16/Res.5, adopted at the $13^{\text {th }}$ plenary meeting, 14 December 2017.

${ }^{59}$ M. Schmitt, State Opinio Juris and International Humanitarian Law Pluralism, 91 International Law Studies 171-215, 2015.

${ }^{60}$ Koh illustrated this argument with reference to the killing of Anwar Al Aulaqi, which the US government only acknowledged two years later and only then offered legal justification. H. Koh The legal adviser's duty to explain, 41 Yale Journal of International Law 2016, pp. 189-211, p. 207. See generally, A. H. Perina, Black holes and open secrets: the impact of covert action on international law, 53 Columbia Journal of Transnational Law, 2015, pp. 507-583.
} 
and Forensic Architecture. ${ }^{61}$ While third States may often be reticent to express claims of illegality, ${ }^{62}$ exemplified by the deafening silence over Yemen, private actors are not governed by similar diplomatic instincts. Hence, different actors are driven by different interests, and while States may make strategic use of Article 51 letters to expand the law on the one hand, they may be ambiguous as to precise legal basis and reserved in providing factual evidence on the other. A more structured approach to Article 51's reporting requirement could thus well serve as a counterfailing force to such dynamics.

\section{Widening the reporting requirement to intervention by invitation ${ }^{63}$}

The initial rationale of Article 51's reporting requirement was to alert the Security Council that force in self-defence had been used and to place the matter on the international agenda with a view to enabling the Council to exercise its primary responsibility to maintain peace and security. ${ }^{64}$ As the system of collective security is becoming more decentralized and as the Security Council has been adopting a new role recently whereby it condones and/or blesses non-authorized uses of force rather than authorizing use of force itself, ${ }^{65}$ the reporting requirement has taken on new meaning. In such constellation, the purpose of the reporting requirement is not mainly to notify or alert so that the Council can take over, but rather to report in the ordinary sense, namely to offer information and to account so as to enable the Security Council and the international community at large to discuss whether the use of force was in accordance with the applicable rules and requirements.

In addition to self-defence as an exception, consent is also relied on to justify the use of force and it has increasingly been invoked as an additional basis for counter-terrorism operations. Also in the context of consent-situations, a practice has emerged whereby the Security Council refrains from authorizing use of force itself, and instead it may appraise the circumstances surrounding the formulation of the invitation thereby endorsing the consent. Whether the Security Council makes such appraisal in concrete situations depends, inter alia, on whether the use of force is reported and whether the matter is placed on the Security Council's agenda. This raises the question regarding the existence of a reporting requirement for consent-based use of force.

Since the UN Charter is silent on intervention by invitation, any legally binding reporting requirement would have to be construed under customary international law. Scholarly arguments have been made in this respect, proposing that Article 51's reporting requirement

\footnotetext{
${ }^{61}$ www.forensic-architecture.org

${ }^{62}$ See on normative effects of silence, P. Starski, Silence within the process of normative change and evolution of the prohibition on the use of force: normative volatility and legislative responsibility, 4 Journal on the Use of Force and International Law 1: 14-65.

${ }^{63}$ This section was also published in slightly different form as L. van den Herik, Replicating Article 51; A reporting requirement for consent-based use of force, part of: Impulses from the Max Planck Trialogues, Heidelberg Journal of International Law (forthcoming in 2019).

${ }^{64}$ James A. Green, “The Article 51 Reporting Requirement for Self-Defense Actions”, in 55 Virginia Journal of International Law 3, 2015, p. 568.

65 As also discussed by M. Hakimi, “The Jus Ad Bellum's Regulatory Form” 112 American Journal of International Law 2, 2018, pp. 151-90.
} 
should be applied mutatis mutandis to consent-based use of force. ${ }^{66}$ In its Resolution on military assistance on request, the Institut de Droit International also stated that "any request that is followed by military assistance shall be notified to the Secretary-General of the United Nations." 67 Suggesting the Secretary-General as recipient of notifications rather than the Security Council might be explained by political sensitivities and reluctance of States to accept any hard core reporting obligation. In this vein, the following US statement may be noted when reporting on missile strikes in Houthi-controlled territory in Yemen in 2016,

"These actions were taken with the consent of the Government of Yemen. Although the United States therefore does not believe notification pursuant to Article 51 of the Charter of the United Nations is necessary in these circumstances, the United States nevertheless wishes to inform the Council that these actions were taken consistent with international law.”68

This can be read as implying that no reporting requirement exists at all, or that Article 51 cannot serve as a legal basis for a reporting requirement on consent-based use of force. It is, in any event, not self-evident to construe a legally binding reporting requirement for consent-based use of force under customary international law. Even if there is a certain practice of informing the Security Council of forceful action taken pursuant to an invitation, ${ }^{69}$ there are also clear examples of non-reporting. ${ }^{70}$ Reporting on consent-based use of force may be sensitive in particular when the consent is not public. Moreover, to construe a customary reporting rule for consent-based use of force, there also needs to be opinio iuris which at this point in time does not necessarily seem to clearly exist (yet). States outside the Security Council as well as nonpermanent members could perhaps play a role in contributing to the expression and formation of such opinio iuris. In this regard, Brazil's statements in 2018 are noteworthy as it insisted on a more meaningful reporting requirement for Article $51,{ }^{71}$ as well on the need for periodic reporting on military operations pursuant to Article 42 of the UN Charter, ${ }^{72}$ thus suggesting a more holistic reporting requirement.

\footnotetext{
${ }^{66}$ Karine Bannelier and Théodore Christakis, "Under the UN Security Watchful Eyes: Military Intervention by Invitation in the Malian Conflict”, 26 LJIL, 2013, pp. 855-874, p. 870. And more tentatively, O. Corten, Intervention by Invitation: The Expanding Role of the UN Security Council, in A. Peters and C. Marxsen, Max Planck Trialogues on the Law of Peace and War Volume IV: Intervention by Invitation (forthcoming).

${ }^{67}$ IDI, Present Problems of the Use of Force in International Law, Sub-Group C - Military assistance on request, Rhodes, 20111, Rapporteur : M. Gerhard Hafner.

${ }^{68}$ Letter dated 15 October 2016 from the Permanent Representative of the United States of America to the United Nations addressed to the President of the Security Council, UN Doc. S/2016/869, 17 October 2016.

${ }^{69}$ E.g., Saudi Arabia in Yemen, the USA in Iraq, Russia in Syria, France in Mali, and Senegal in the Gambia.

${ }^{70}$ See A. Deeks, A Call for Article 51 Letters, Lawfare, 25 June 2014. On US non-reporting of its drone strikes and other operations in Yemen, Somalia and Pakistan, see Columbia Law School Human Rights Clinic and Sana'a Center for Strategic Studies, Out of the Shadows Recommendations to Advance Transparency in the Use of Lethal Force, June 2017, p. 54. Also see D. Bosco, Letters from the Front Lines: State Communications to the U.N. Security Council During Conflict, 54 Columbia Journal of International Law 341-381 (2016).

${ }^{71}$ Statement by Brazil in the UN General Assembly (Sixth Committee) debate on the report of the Special Committee on the Charter on the United Nations, 15 October 2018, available at: http://statements.unmeetings.org/media2/20303642/brazil-85.pdf.

${ }^{72}$ Statement by H.E. Ambassador Mauro Vieira in the UN Security Council open debate on upholding international law within the context of the maintenance of international peace and security, 17 May 2018, UN Doc. S/PV.8262, at pp. 44-45. On effective monitoring and accountability, also see Brazil's Concept Paper on Responsibility while protecting: elements for the development and promotion of a concept, UN Doc. A/66/551

S/2011/701, 11 November 2011, para. 11 (h) and (i).
} 
In considering a reporting requirement for consent-based use of force specifically, complex questions arise on timing and modalities as well as on when and how consent-based use of force that is very temporary or that involves a one off action must be reported, and on what exactly must be reported under this heading, i.e., whether a reporting requirement would also cover pure aiding.

Absent a clear requirement thus far, States nonetheless tend to rely on multiple justifications including consent and they have reported on this to the Security Council. Given this existing practice, the issue whether a perceived duty to explain translates into a hard legal obligation to report and whether this obligation extends to consent-based use of force in addition to selfdefence is perhaps not the most pressing one. Even absent overall agreement that reporting on all uses of force is legally required, States have in fact reported beyond Article 51's requirement or at least they are often inclined to make statements that are meant to be explanatory. The bigger problem is that the reporting and related discourse is not always centralized and sometimes done at other venues such as the Human Rights Council, the EU, domestic parliaments, or the media. A second bigger problem concerns ambiguous and/or superficial language and absence of reasoning, legal argument and failure to adduce any supporting factual material and evidence. ${ }^{73}$ This raises the question how States may be persuaded to engage in more structured and meaningful reporting and use of force discourse.

\section{Enhancing use of force discourse: lessons from the UN sanctions architecture}

Enhancing use of force discourse presupposes the creation or existence of an enabling environment which entices States invoking self-defence and/or justificatory grounds to take part in the conversation in a meaningful way and which similarly animates third States to challenge or scrutinize claims of self-defence and other justifications. What should such an “enabling environment” look like? ${ }^{74}$

The most sophisticated institutional architecture that exists at Security Council level has been designed in the past decades in UN sanctions and counter-terrorism context. It may be explored to what extent ideas to build a more elaborate enabling environment to discuss claims of selfdefence and other justifications of unilateral use of force can be patterned upon the bodies or platforms created as part of the UN sanctions architecture.

\footnotetext{
${ }^{73}$ On strategic ambiguity, see M. Milanovic, Belgium's Article 51 Letter to the Security Council [UPDATED], EJIL: Talk!, 17 June 2016. On intentional ambiguity within the Security Council, outside a context of self-defence, also see M. Byers, Agreeing to Disagree: Security Council Resolution 1441 and Intentional Ambiguity, 10 Global Governance 165-186 (2004).

${ }^{74}$ On the Security Council as a forum for justificatory discourse, see also I. Johnson, Security Council Deliberations: The Power of Better Argument, 14 European Journal of International Law 3: 437-480 (2003), pp. 452-464. On reason giving in the Security Council, also see D. Moeckli and R.N. Fasel, A Duty to Give Reasons in the Security Council: Making Voting Transparent, 14 International Organizations Law Review (2017) 13-86. Both articles rely on Jürgen Habermas’ theory of communicative action.
} 
The elaborate UN sanctions machinery is, in a sense, quite spectacular given the Security Council's reticence to settling on any generic procedures or working methods. ${ }^{75}$ Despite the Council's preference for ad hoc-ism which better allows it to keep control, a certain UN sanctions apparatus including notable elements of independence has come into place. An important component of the UN sanctions architecture are the sanctions committees, which are created under Article 29 of the UN Charter as subsidiary organs. Each UN sanctions regime has its own sanctions committee, which is composed of the 15 members of the Security Council. The core mandate of a sanctions committee is to monitor implementation, which includes the listing of individuals that are to be subjected to sanctions. The exact working methods and procedures differ per sanctions regime, although recent streamlining attempts have been made pursuant to external criticisms on the political and arbitrary nature of the functioning of these committees. These criticisms were particularly strong in the context of the Taliban / Al Qaeda / Daesh sanctions, which ultimately led to the creation of the Ombudsperson for this sanctions regime. $^{76}$ The Ombudsperson was established for the Al Qaeda sanctions regime only. When the Taliban / Al Qaeda sanctions split up in two separate sanctions regimes, the Taliban sanctions regime was brought outside of the scope of the Ombudsperson's "jurisdiction". ${ }^{77}$ Yet, when the Al Qaeda sanctions regime was expanded to also cover IS in 2015, the Ombudsperson's powers grew along accordingly. ${ }^{78}$

The Ombudsperson can receive petitions by individuals to be delisted and its mandate and procedures are detailed in Resolutions 1904 (2009), 1989 (2011), 2083 (2012), 2161 (2014), 2253 (2015), 2368 (2017). The Ombudsperson can recommend delisting which will take effect unless the sanctions committee disagrees by consensus or refers the matter to the Security Council. ${ }^{79}$ This procedure has been criticized by human rights lawyers as not offering fair process to individuals since a recommendation is not binding, yet such criticism fails to recognize the revolutionary step that the Security Council took to accept a nearly binding independent second opinion in its decision-making processes. ${ }^{80}$ The Ombudsperson process is also interesting in its treatment of confidential information. For instance, Resolution 2368 (2017) encourages States to offer as much information as possible that can serve as a statement of case explaining the reasons why a person has been listed, and it also indicates that this statement of case shall be releasable. ${ }^{81}$ Obviously, there may be intel involved and underlying the listing proposals, but this does not necessarily need to be disclosed if sufficient reasons can be given otherwise, for instance based on open source materials. In this respect, it is interesting to note that certain actors, such as the UK and the European Union, have indicated that they are

\footnotetext{
${ }^{75}$ See for a similar finding and a general appraisal of the UN sanctions apparatus, J. Weschler, The evolution of Security Council innovations in sanctions, International Journal, 2009/10, pp. 31-43.

${ }^{76}$ See for an analysis, K. Prost, Security Council sanctions and fair process, in L. van den Herik (ed.), UN Sanctions and International Law, Edward Elgar Publishing, 2017, pp. 213-235.

${ }^{77}$ UN Doc. S/RES/1988 and 1989, 17 June 2011.

${ }^{78}$ UN Doc. S/RES/2253, 17 December 2015.

${ }^{79}$ UN Doc. S/RES/2161, 17 June 2014, para. 43 and annex II, para. 14.

${ }^{80}$ See also D. Hovell, The Power of Process; The Value of Due Process in Security Council Sanctions DecisionMaking, OUP, 2016.

${ }^{81}$ UN Doc. S/RES/2368, 20 July 2017, para. 51.
} 
turning to open source information to substantiate domestic listings pursuant to UN and EU designations with a view to circumventing disclosure problems. ${ }^{82}$

Attempts to broaden the Ombudsperson process to other regimes have failed so far, and this reluctance is mainly inspired by a desire to keep the fullest control possible over nonproliferation regimes. ${ }^{83}$ Yet, all UN sanctions regimes do have - on paper - independent elements in the form of panels of experts. These experts are appointed by the Secretary-General, after consultation with the Sanctions Committee. Typically, the experts assist the Committee in carrying out its mandate, including through providing information relevant to the potential designation of individuals and entities, and they also assist the Committee in refining and updating information on the list of individuals subject to the assets freeze, travel ban, and targeted arms embargo, including through the provision of identifying information and additional information for the publicly-available narrative summary of reasons for listing. The experts thus have a strong fact-finding mandate and they are tasked to gather, examine and analyse information from States, relevant United Nations bodies, regional organisations and other interested parties regarding the implementation of the sanctions. It is already the case that information gathered by panels of experts may have jus ad bellum relevance. For instance, the panel of experts for Yemen has reported on the relationship between Iran and the Houthi's, a factor of relevance to proportionality assessments in the context of the consent-based use of force by the Gulf Coalition Forces. ${ }^{84}$

The panels of experts do not receive much guidance on how to find and establish facts and they are largely dependent on State cooperation. Nonetheless, procedural advancements are being made with a view to ensure proper fact-finding, and the investigative methodology developed by the panel of experts for Yemen is particularly instructive in this regard. ${ }^{85}$ This panel has also begun to use social media, commercial satellite imagery and navigation-tracking databases for its fact-finding exercises. ${ }^{86}$ Also in the more comprehensive sanctions regimes, such as the nonproliferation regimes, panels of experts are part of the apparatus. Their level of independence may be slightly more circumspect, as was illustrated by a recent incident in which Russia allegedly suppressed parts of an expert panel report that detailed Russian sanctions evasion. ${ }^{87}$ But this example can also be taken as indicative of the independent potential of panels of experts.

\footnotetext{
${ }^{82}$ See e.g. UK House of Lords, The Legality of EU Sanctions, European Union Committee Report, February 2017, paras. 105 and 106.

${ }_{83}$ L. van den Herik, Peripheral hegemony in the quest to ensure Security Council accountability for its individualized UN sanctions regimes, 19 Journal of Conflict and Security Law 1: 427-449 (2014).

${ }^{84}$ B. Nussberger, Military strikes in Yemen in 2015: intervention by invitation and self-defence in the course of Yemen's 'model transitional process', 4 Journal on the Use of Force and International Law 1, (2017), pp. 110160, p. 139.

${ }^{85}$ Final report of the panel of experts on Yemen, UN Doc. S/2017/81, 31 January 2017, annexes 1 and 2, pp. 6266.

${ }^{86}$ Final Report of the Panel of Experts on Yemen, UN Doc. S/2017/81, 31 January 2017, pp. 7-8.

87 Ambassador Nikki Haley, Remarks at a UN Security Council Briefing on Nonproliferation and the Implementation and Enforcement of UN Sanctions on North Korea, U.S. Mission to the United Nations, 17 September 2018, as also reported by Julian Borger, US accuses Russia of covering up North Korea sanctions violations, The Guardian, 17 September 2018.
} 
Obviously the legal framework governing UN sanctions is very different from the rules on jus ad bellum and self-defence specifically. UN sanctions have come to be more focused on individuals, which has been one of the incentives for the push towards proceduralization. Nonetheless, some of the elements of the UN sanctions architecture may still be useful as a very general blueprint for thinking about ways to design an enabling environment for use of force discourse. Currently, not all use of force communication is always done in the form of formal reporting letters. Other types of written State communications may include use of force discourse too. Information can also be shared orally in Security Council meetings, to which involved State may be invited also if they are not member of the Security Council pursuant to Article 32 but only if the concrete use of force in which they are involved is placed on the agenda. Even information that is presented at Security Council level thus remains scattered. Academic initiatives may fill the void, such as the Harvard Law School databases, ${ }^{88}$ but these should not replace formal structures or the need to develop more refine institutional structures at Security Council level.

To be more concrete, proceduralizing Article 51 and concomitant reporting obligations could include some of the following:

- Placing unilateral use of force on the Security Council agenda.

- Holding a routine debate once Article 51 or another jus ad bellum justificatory ground is invoked.

- $\quad$ The set up of a database collecting Article 51 and other reporting letters.

- Developing best practices on when exactly and how often letters should be submitted.

- Developing best practices on what letters should contain.

- The creation of a subsidiary body that collects and monitors submission of Article 51 and other letters.

- The creation of panels of experts to gather, examine and analyse relevant information from States, including from third States, and possibly to make prima facie evaluations. ${ }^{89}$

A modest role for independent panels of experts would reflect the interests that the entire international community has in upholding the prohibition of the use of force as a central norm.

\section{Conclusion}

This chapter has presented the argument that Article 51's reporting requirement goes beyond mere notification, and that it also demands that States make formal articulations on the scope of self-defence in concrete situations and that they make an effort to substantiate claims of selfdefence, both legally and factually. This call seems to conflict with recent concerns expressed by the CELAC over "the increase in the number of letters to the Security Council under Article 51 of the Charter submitted by some States in order to have recourse to the use of force in the context of counter-terrorism, most of the times "ex post facto"." 90 Also the NAM has underlined

\footnotetext{
${ }^{88}$ Available at https://pilac.law.harvard.edu/about-menu/.

${ }^{89}$ See for similar suggestions put forward by Brazil, fn. 71 .

${ }^{90}$ Measures to Eliminate International Terrorism, Statement by the Permanent Mission of the El Salvador to the United Nations on Behalf of the Community of Latin American and Caribbean States (CELAC), New York, 2 October 2017.
} 
that "Article 51 of the UN Charter is restrictive and should not be re-written or re-interpreted." One-sided Article 51 letters can indeed have this effect of rewriting the exception of selfdefence. The argument regarding a deepening and widening of the reporting requirement must thus be connected with broader reflections on how to create a space for formal self-defence discourse. Such a space should encourage and facilitate all States, including third States, to be explicit in their position on the scope of self-defence and other uses of force. Broad participation in use of force discourse is essential given the central place of Article 2(4) of the UN Charter and it being a cornerstone of our international legal order. As noted by Oona Hathaway, "States that do not use force need to be more active in voicing their legal positions. If the only States that take legal positions on the use of force are those using force, the exceptions will continue to expand until they swallow the rule."92 Some consideration of countervailing structures at Security Council level might therefore not be superfluous.

\footnotetext{
${ }^{91}$ 17th Summit of Heads of State and Government of the Non-Aligned Movement, Island of Margarita, Bolivarian Republic of Venezuela, 17 - 18 September 2016, NAM 2016/CoB/DOC.1. Corr.1, para. 25.2.

${ }^{92}$ O. Hathaway, Twitter, 23 October 2018.
} 